\title{
Functional and technological attributes of probiotic yoghurt prepared with Dahi micro-flora during refrigerated storage
}

\author{
Talat MAHMOOD ${ }^{1,2}$, Tariq MASUD ${ }^{3}$, Abdul QAYYUM ${ }^{4}$, Ayaz MEHMOOD ${ }^{5 *}$, Waseem AHMED ${ }^{6}$, \\ Muhammad LIAQUAT ${ }^{2}$, Muhammad Javed TAREEN ${ }^{7}$, Sami Ullah KHAN ${ }^{4}$, Sartaj ALI ${ }^{8}$
}

\begin{abstract}
In the present investigation functional, technological, and rheological attributes of probiotic yoghurt were studied during refrigerated storage $\left(4^{\circ} \mathrm{C}\right)$ for 28 days. The different preparations of probiotic yoghurts were made from dahi microflora which was documented as probiotics. Three strains of lactic acid bacteria (LAB) i.e. S. thermophilus (S02FT), L. bulgaricus (TLB06FT) and $L$. acidophilus (LA06FT) were selected for formulations of probiotic yoghurt. Three sets of probiotic yoghurt including Y1: S02FT and TLB06FT (1:1 ratio), Y2: S02FT and TLB06FT (1:2ratio) and Y3: S02FT, TLB06FT and LA06FT (1:1:1 ratio) along with $\mathrm{Y} 0$ as a control (non-probiotic strains) were prepared and stored at $4{ }^{\circ} \mathrm{C}$ for 28 days. The results showed that technological attributes of $\mathrm{Y} 3$ preparation had better lactic acid production (75\% at 0 day and $93 \%$ at 28 days) as compared to control. Moreover, Y3 preparation had lesser synersis ( $20 \%$ at 0 day and $35 \%$ at 28 days) as compared to other treatments i.e.Y1, Y2, Y0 that had 24,70 and $18 \%$ synersis at 0 day of storage respectively). However, viscosity of Y3 probiotic yoghurt indicated higher values (3001 cP at 0 days and $1310 \mathrm{cP}$ at 28 days) among the rest of preparations. Functional attributes of $\mathrm{Y} 3$ showed the better results such as viability of probiotics $\left(40 \times 10^{-6} \mathrm{CFU} / \mathrm{ml}\right.$ at 0 day and $1.16 \times 10^{-6} \mathrm{CFU} / \mathrm{ml}$ at 28 days $)$ and antibacterial activity $(7.5 \mathrm{~mm}$ at 0 days $7 \mathrm{~mm}$ at 28 days) compared to other preparations. Conclusively, Y3 formulation attained the higher sensory attributes due to its better lactic acid production, viscosity and lesser synersis values during entire study duration in formulated yoghurt.
\end{abstract}

Keywords: yoghurt; probiotics; antibacterial activity; cold storage; sensory evaluation; syneresis; viscosity.

Practical Application: Fermented milk products and used as yoghurt.

\section{Introduction}

Dahi is indigenous probiotic yoghurt prepared from wild strains of lactic acid bacteria which is deliberated as natural therapy for gastro-intestinal problems from decades (Patel et al., 2018). It is a rich source of friendly bacteria along with other useful food constituents like omega-3 fatty acids, whey proteins, minerals and vitamins (Weerathilake et al., 2014). It has whitish to light pale color depending upon the source of milk, having sweet sour taste, very pleasant aroma and soft texture (Harun-ur-Rashid et al., 2007). The consumption of Dahi is increasing gradually due to its potential beneficial effects on physiological functions. Main contribution in the therapeutic nature of Dahi is due to the presence of various probiotic strains including $L$. mesenteroides spp. cremoris, L. bulgaricus, S. themophilus, L. reuteri, L. casei, $L$. planetarium and L. acidophilus etc. These strains are not only imparting probiotic features but also conferring the technological preference (Tsiraki et al., 2017). Additionally, viability of these strains in human body has great significance and is affected by several factors such as type of microorganisms, their symbiotic relationships, source of isolation and tolerance to acid and bile etc. (Kavas \& Gokhan, 2016).Characterization of these wild strains and their application for the preparation of probiotic milk products is more relevant and attractive to both general public and food manufacturers (Giraffa, 2012).

The demand of probiotic products has increased significantly in the recent years because consumers are more concern about their health (Mattila-Sandholm et al., 2002). According to a survey, it has been estimated that global probiotic market is growing at the rate of $11.7 \%$ annually (Keogh \& O'Kennedy, 1998) therefore; different agencies are attempting to target various foods for probiotic inclusion. They are adding probioitcs in confectionary, fruit drinks and fermented dairy products to get maximum health benefit (Theunissen $\&$ Witthuhun, 2004). Bio-yoghurt or probiotic yoghurt is another popular fermented dairy product that is being used for provision of probiotic cultures to consumers (Ali et al., 2013).There are many

\footnotetext{
Received 14 Apr., 2017

Accepted 09 Sept., 2018

${ }^{1}$ Food and Nutrition Division, Nuclear Institute for Food and Agriculture, Peshawar, Pakistan

${ }^{2}$ Department of Food Science \& Technology, The University of Haripur, Pakistan

${ }^{3}$ Department of Food Technology, PMAS-Arid Agriculture University Rawalpindi, Pakistan

${ }^{4}$ Department of Agronomy, The University of Haripur, Pakistan

${ }^{5}$ Department of Soil Science, The University of Haripur, Pakistan

${ }^{6}$ Department of Horticulture, The University of Haripur, Pakistan

${ }^{7}$ Agriculture Research Institute, Sariab, Quetta, Pakistan

${ }^{8}$ Department of Agriculture \& Food Technology, Karakoram International University, Gilgit, Pakistan

*Corresponding author: ayaz.gill@uoh.edu.pk
} 
processing operations that help the probiotic bacteria to maintain and enhance probiotic features including, addition of antibiotic, cold and heat stress etc. (Granato et al., 2010). Similarly, addition of oxidase enzymes helps in viability of these probiotics during storages (Cruz et al., 2013). However, many reports revealed that probiotic bacteria loss their viability and capabilities during storage (Akalin et al., 2012). This might be due antagonistic effects of mix culture that cease the production of antibacterial compound or loss of probiotic nature. In this context, the present study was designed to investigate the functional, technological and rheological attributes of probiotic yoghurt formulated by wild strain of bacteria isolated from locally available dahi during refrigeration storage.

\section{Materials and methods}

Bacterial strains and growth media: The isolated wild strains of lactic acid bacteria from dahi such as L. acidophillus (LA06FT), L. bulgaricus (TLB06FT) and S. thermophills (S02FT) were collected from Culture Collection Center of Food Microbiology Laboratory (CCC-FBL), Department of Food Technology, PMAS-Arid Agriculture University Rawalpindi, Pakistan. For lactobacilli selective media of MRS-CM 0359 (de Man, Rogosa Sharpe) and for lactococci M-17 (Oxide, Ltd. Hampshire England) were used. Indicator strains like Listeria monocytogens-ATCC19115, Staphylococcus aureus-ATCC 6538, Pesudomonas aeruginosa-ATCC 25923 and Escherichia coliATCC-25922 were contributed by Pakistan Institute of Medical Sciences (PIMS).

Preparation of Probiotic yoghurt: Three combination of probiotic yoghurt were prepared along with control (yoghurt with non-probiotic strains). The basis for these combinations are to identify the best possible combination for technological, functional and sensory evolution aspect. Three probiotic yoghurt were prepared by using different combination of lactic acid bacteria (LAB) detail of preparations was as under

Y0: L. bulgaricus (TLB07FT) and S. thermophillus (ST01FT) in 1:2 ratio i.e. control with non-probiotic

Y1: L. bulgaricus (TLB06FT) and S. thermophillus (ST02FT) in $1: 1$ ratio.

Y2: L. bulgaricus (TLB06FT) and S. thermophillus (ST02FT) in $1: 2$ ratio.

Y3: L. bulgaricus (TLB06FT), S. thermophillus (ST02FT) and L. acidophilus (LA06FT) in 1:1:1 ratio.

The preparation was incubated at $42^{\circ} \mathrm{C}$ for $3 \mathrm{hrs}$. The prepared yoghurts were stored at $4{ }^{\circ} \mathrm{C}$ and were analyzed for set parameters on 7 days intervals.

Procedure for yoghurt manufacturing: Probiotic yoghurt was prepared according to the procedure described by Wang et al., (2010). Buffaloe's milk was standardized and homogenized to $3.5 \%$ and $12 \mathrm{~g} / 100 \mathrm{~mL}$ total sold and then supplemented with $5 \mathrm{~g} / 100 \mathrm{~mL}$ of sucrose. The mixture was homogenized and heated on water bath for $5 \mathrm{~min}$ at $95^{\circ} \mathrm{C}$ and cooled quickly to $42^{\circ} \mathrm{C}$. The culture in above combinations were added separately, mixed and transferred two glass cups. These cups were incubated at $42{ }^{\circ} \mathrm{C}$ and shifted to refrigerator when $\mathrm{pH}$ dropped to 4.6. Schematic flow diagram for the preparation of yoghurt is presented in Figure 1.

Technological attributes of probiotic yoghurt in term of change in $\mathrm{pH}$ : $\mathrm{pH}$ was estimated as per the procedure described by Association of Official Analytical Chemists (2000) method no. 981.12 and expressed as $-\log$ of $\mathrm{H}^{+}$.

Titratable acidity: Titratable acidity of probiotic yoghurts were measured according to the method described in the Association of Official Analytical Chemists (2000) method no. 967.16. Some procedural changes were made to execute the experiment. Yoghurt sample $(4.5 \mathrm{~mL})$ was mixed with equal amount of distilled water in test tube $(10 \mathrm{~mL}$ capacity) and homogenized using the vortex mixture for $10 \mathrm{~min}$. Resultant sample was titrate with $1 \mathrm{~N} \mathrm{NaOH}$ by using the phenolphthalein indicator. Results were expressed as Gram Equivalent Weight in term of Lactic acid.

Syneresis: Syneresis of prepared probiotic yoghurt was estimated by the process of centrifugation as reported by Keogh \& O’Kennedy (1998). Twenty gram of sample was taken in centrifuge tubes and mixture was centrifuged for $10 \mathrm{~min}$ at $1000 \mathrm{~g}$.

Syneresis $(\%)=\frac{\text { Weight of supernatant }(g)}{\text { Weight of yoghurt sample }(g)} \times 100$

(Equation 1)

Viscosity: The apparent viscosity of the samples was determined by the method as described by Wang et al. (2010). Viscosity was measured on Brookfield DV-1 Viscometer equipped with spindle No. 2 running at $100 \mathrm{~g}$ (Brookfield Engineering Laboratories, Inc, Middle-bore, MA, USA). Results were noted at $30^{\text {th }}$ second and torque was kept between 10 to $100 \%$.

Functional attributes of probiotic yoghurt: antagonistic activity of lactic acid bacteria: Antagonistic activity was examined to assess the compatibility of three strains used for yoghurt production. Cell free supernatant of overnight grown culture was applied against selected strains and results were expressed as inhibition zone ( $\mathrm{mm}$ ) as reported by Saccaro et al. (2009).

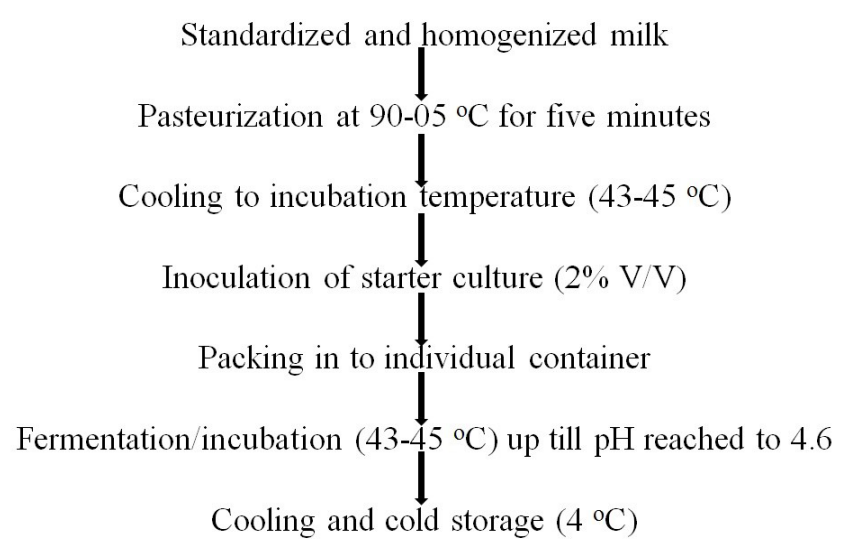

Figure 1. Schematic flow diagram for the preparation of yoghurt. 
Total viable count: Total viable count in yoghurt was measured by serial dilution method as reported by Wang et al. (2010). MRS and M-17 selective media for Lactococci and Streptococci were used, respectively.

Antimicrobial activity of whey: Paper disc method was applied to determine the antimicrobial activity in the whey as per the reported method of Hoover \& Harlander (1993). Supernatant free from cell was collected by centrifugation for $10 \mathrm{~min}$ at $8000 \mathrm{rpm}$ and its $\mathrm{pH}$ was adjusted at 5.5.

Resultant sample was sterilized by passing through $0.45 \mu \mathrm{m}$ filter. Sterilized sample $(10 \mu \mathrm{m})$ was applied against the indicator strains. The antibacterial activity was measured as reciprocal of titer in the highest dilution $\left(2^{\mathrm{n}}\right)$ that inhibit the indicator strain i. e. $\mathrm{AU}=2^{\mathrm{n}} \times 1000 / 10 \mu \mathrm{L}$

Sensory evaluation of yoghurt: The formulated probiotic yoghurts were evaluated by the trained panel of seven judges as per nine point's hedonic scale for sensory evaluation described by Larmond (1977).
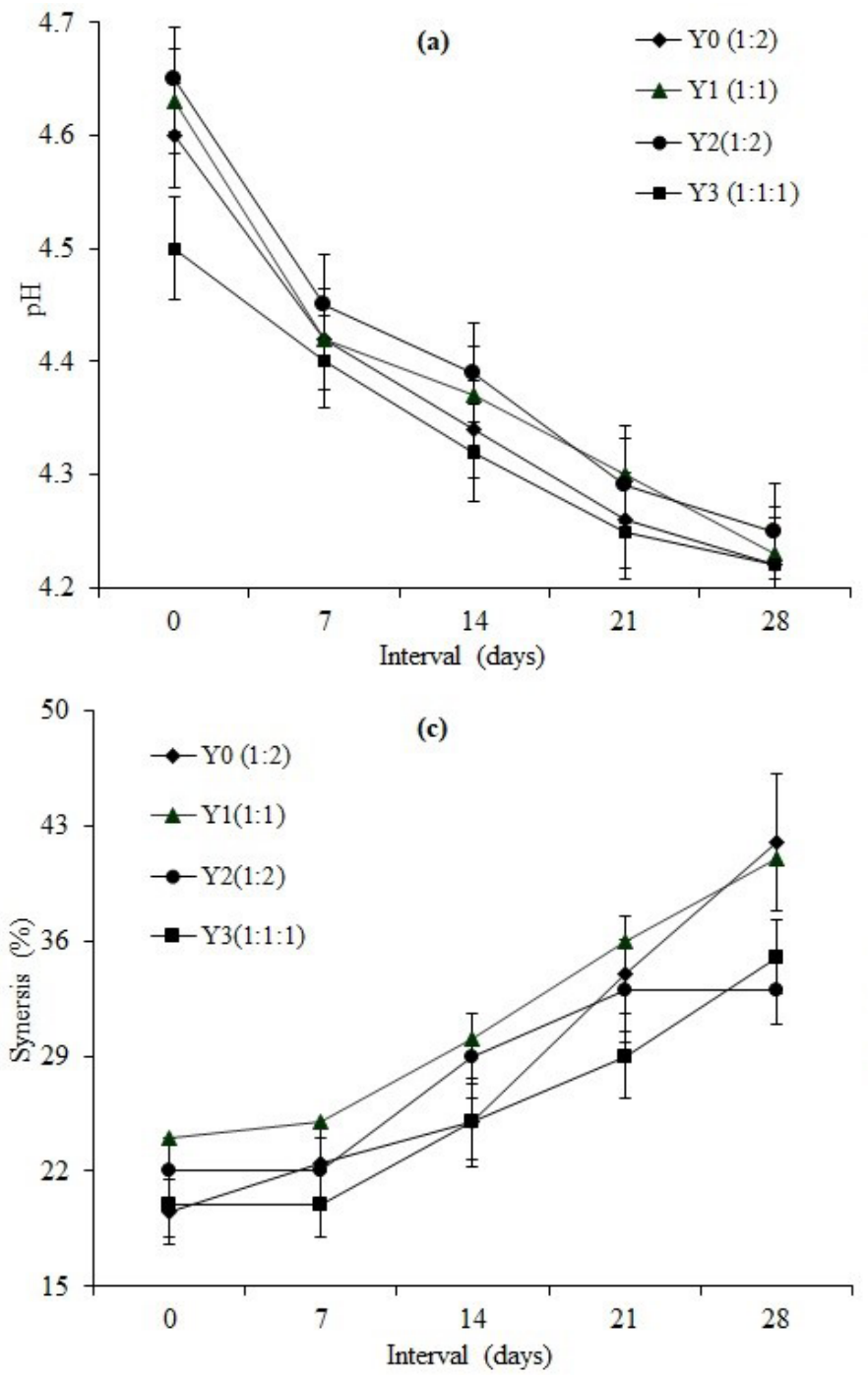

Statistical analysis: Means and standard deviation were calculated from three replicates by using the Microsoft excel (2007). The results of sensory evaluation is analyzed by the analysis of variance technique using the MSTAT-C statistical package (when significant differences, i.e. $\mathrm{P}<0.05$, were found), and Duncan's multiple range test (DMRT) was used to determine the differences among the means (Steel et al., 1997).

\section{Results and discussion}

pH: The $\mathrm{pH}$ values of probiotic yoghurt were exhibited the significant variations with respect to strains, storage and their interaction. Change in $\mathrm{pH}$ during refrigerated storages was illustrated in the Figure 2a. At 0 day $\mathrm{pH}$ of control (Y0) sample was 4.50 and for other preparations it was noticed as 4.65 (Y1), 4.63 (Y2) and 4.60 (Y3). There was a gradual decreased in $\mathrm{pH}$ was noticed during storage and after 28 days the values of $\mathrm{pH}$ was found as 4.28, 4.25, 4.23 and 4.22 for Y0, Y1, Y2 and Y3 respectively. The slight change in $\mathrm{pH}$ during cold storage is known as post acidification phenomenon previously reported
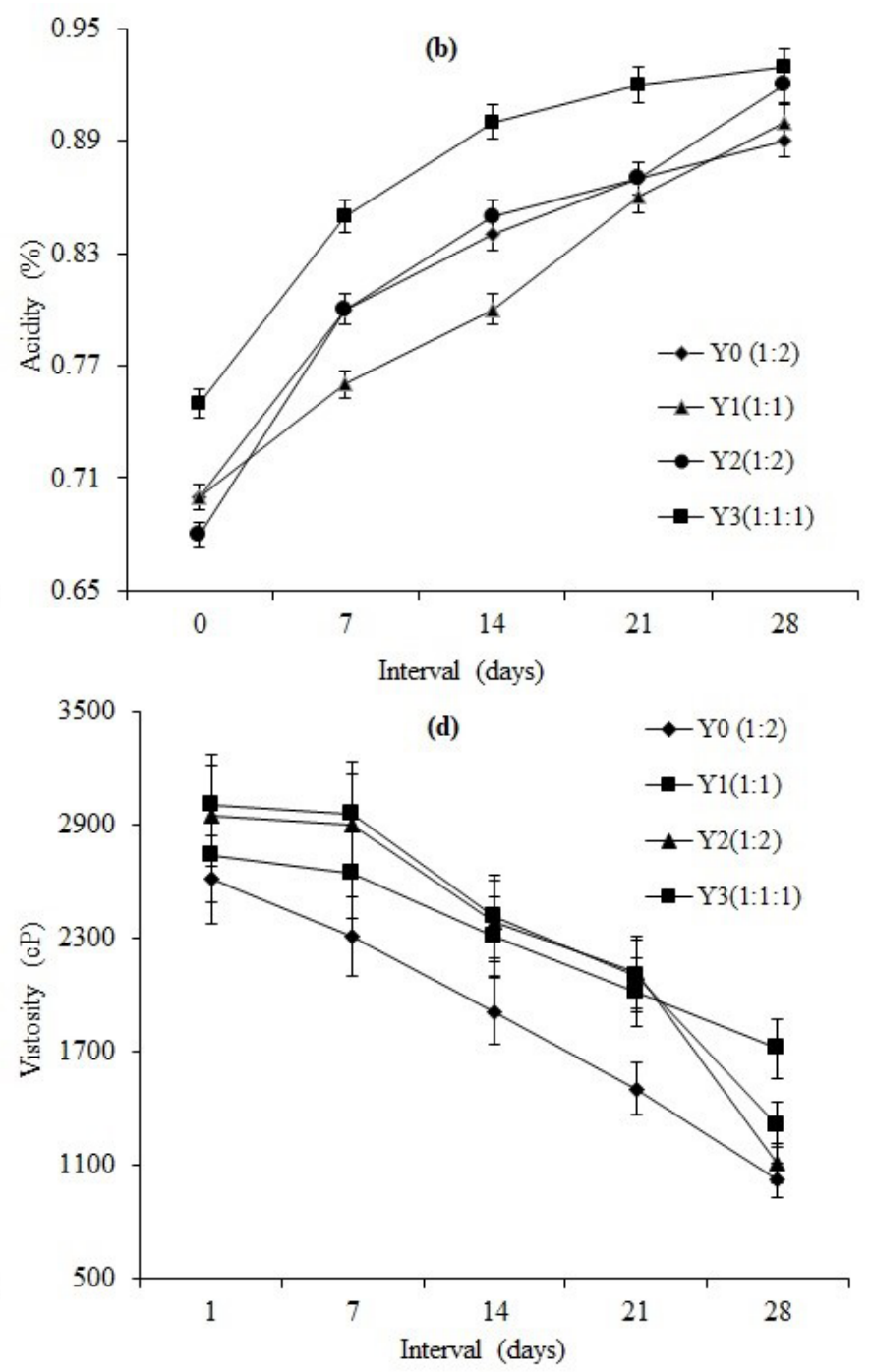

Figure 2. Technological attributes of probiotic yoghurt as (a) pH, (b) titrateable acidity (c) syneresis and (d) viscosity. 
by Donkor et al. (2007). They reported that the $\mathrm{pH}$ of yoghurt was declined from 4.45 to 4.21 during cold storage. Similarly, Wang et al. (2010) also observed the non-momentous gradual decline in $\mathrm{pH}$ whereas significantly $(\mathrm{P}<0.05)$ decrease was reported during storage of this parameter. In present study the decreasing trend of $\mathrm{pH}$ was found higher in $\mathrm{Y} 3$ as compared to other preparations which are indication of higher level of viability of cultured probiotic bacteria. Earlier, Kavas \& Gokhan (2016) delineated that the $\mathrm{pH}$ level of probiotic yoghurt was decreased.

Titratable acidity: Titratable acidity (TA) of formulated yoghurt's combination was varied significantly in both treatments and storage intervals (Figure $2 \mathrm{~b}$ ). First day the maximum TA was exhibited by Y0 ( $0.75 \%)$ followed by Y3 $(0.72 \%)$, Y2 $(0.70 \%)$ and Y1 (0.68\%), respectively however, the values of TAs were improved steadily during storage (28 days) in all combinations. Maximum increase was noticed in Y3 wherein TA reached to $0.93 \%(\mathrm{v} / \mathrm{v})$ due to the highest viability of probiotic bacteria in Y3 formulation. The present study results are in line with the finding of Georgala et al. (1995), they observed similar changes in the TA of yoghurt during storage. It was observed that Y3 preparation had the highest value of lactic acid contents as in this formulations due to addition of third strain i.e. L. acidophilus was included. Later, Khandelwal et al. (2014) reported that additional of $L$. acidophilus not only enhanced the lactic acid production rate but also improve the sensory characteristics of yoghurt at 28 days storage of yoghurt.

Synersis: Data for syneresis in the various combination of yoghurt showed momentous $(\mathrm{P}<0.05)$ differences as illustrated in the Figure 2c. The maximum syneresis was observed in Y0 $(24 \%)$ and the lowest value of this trait was observed in Y3 $(19.5 \%)$ at 0 day. There was gradual increased in syneresis in all combinations of probiotic yoghurt with increase of storage interval. Trend for whey separation among different combinations showed that the maximum whey was removed from $Y 0$ followed by Y2, Y3 and Y1 respectively, at 28 days of storage. This increasing trend was in accord with the results of Lee \& Lucey (2004) that who delineated whey separation from yoghurt was increased with prolonged storage time owing to excessive rearrangement of particles that form gel network in yoghurt which further effects on other rheological parameters. Later, Olson \& Aryana (2008), reported that the extent of syneresis of yoghurt increased by decreasing the $\mathrm{pH}$ value with the passage of time as illustrated by our results. Our findings were in agreement with finding of Nguyen et al. (2014), they revealed the buffalo milk yoghurt prepared by using the L. acidophilus had better firmness after 28 days storage interval as in our study.

Viscosity: The apparent viscosity of probiotic yoghurts and the controlled was illustrated in the Figure 2d. The viscosity of probiotic yoghurt was decreased $(\mathrm{P}<0.05)$ in all treatments and the highest viscosity noted in $\mathrm{Y} 3$ followed by $\mathrm{Y} 2$ and $\mathrm{Y} 1$ whereasthe lowest value of this parameter was noticed inY0. Similarly, storage time also impacted on the viscosity and showed gradual decreased in viscosity value with the passage of time in all treatments. Present findings supported the earlier investigation of Wang et al. (2010) that indicated apparent viscosity of yoghurts made with different combinations culture bacteria showed variations significantly. In the same pattern findings of Donkor et al. (2007) are also harmony with our results as they reported that the decrease in viscosity of probiotic yoghurt after prolog storages and deeply influence by types and concentration of culture bacteria. In contradiction with Aryana \& Mcgrew (2007) findings that observed gradual reduction in the apparent viscosity of probiotic yoghurt but interaction between time interval and treatments was non-significant possibly due the activity of bacteria enzymes on the matrix of casein micelle over the time.

Antagonistic activity of lactic acid bacteria: The antagonistic effect among the selected strains was presented in the Table 1. There was no prominent zone of inhibition indicating non-antagonistic behavior of these strains. It might be due to the same source of isolation or due to the presence of these strains in similar kind of environments. The present results were different from the previous finding of Saccaro et al. (2009) who examined the antagonistic effect against $L$. acidophilus when grown in co-culture in L. rhamnosus, B. animalis sub spp. lactis and yoghurt cultures. Similar findings were also reported by Vinderola et al. (2002) who observed that growth of L. acidophilus is inhibited by the both S. thermophilus and L. bulgaricus.

Viability of lactic acid bacteria during storage: Viable counts of various combination of yoghurt are shown in the Figure 3a. This was observed that viable count progressively decrease in all combinations and found the highest count was noticed in Y3 because three group of culture present which belongs to different species. Gradual decrease in the viable count in all combination with the passage of time was also observed. These results are in line with the findings of Wang et al. (2010) who reported the viability of probiotic bacteria increased initially in the first half of study and then it started to decline with the passage of time. The increase in viable cells of $\mathrm{Y} 1 \mathrm{might}$ be due to the presence to L. acidophilus in this combination that may attribute protolytic activities that favor the cell viability because milk is lacking many amino acids and protolytic activity. Our investigation also support the findings of Bandiera et al. (2013) studies who revealed that $L$. casei showed viability up to $10^{8} \mathrm{CFU} / \mathrm{g}$ during storage period of 21 days. However, they concluded that there are non-significant differences for population of $L$. casei. There was no statistical variation between the population of $L$. casei and formulation except for the first time of storage.

Antibacterial activity of whey: Antimicrobial action of yoghurt water that is commonly known as whey was noted to determine in vitro behavior of probiotic bacteria especially when grown with complex food systems and results are presented on

Table 1. Antagonistic effect of selected probiotic strains against each other.

\begin{tabular}{lccc}
\hline \multicolumn{1}{c}{$\begin{array}{c}\text { Probiotic } \\
\text { cultures Code }\end{array}$} & $\begin{array}{c}\text { S02FT } \\
(\mathrm{AU} / \mathrm{ml})\end{array}$ & $\begin{array}{l}\text { TLB06FT } \\
(\mathrm{AU} / \mathrm{ml})\end{array}$ & $\begin{array}{l}\text { LA06FT } \\
(\mathrm{AU} / \mathrm{ml})\end{array}$ \\
\hline $\begin{array}{l}\text { L. acidophilus } \\
\text { LA06FT }\end{array}$ & $300 \pm 2.0$ & $200 \pm 5.0$ & $000 \pm 0.0$ \\
$\begin{array}{l}\text { S. thermophilus } \\
\text { S02FT }\end{array}$ & $000 \pm 0.0$ & $100 \pm 1.0$ & $300 \pm 2.0$ \\
$\begin{array}{l}\text { L. bulgaricus } \\
\text { TLB06FT }\end{array}$ & $200 \pm 3.0$ & $000 \pm 0.0$ & $100 \pm 2.0$ \\
\hline
\end{tabular}

$000 \pm 0.0$ : indicates that no inhibition zone was present. 

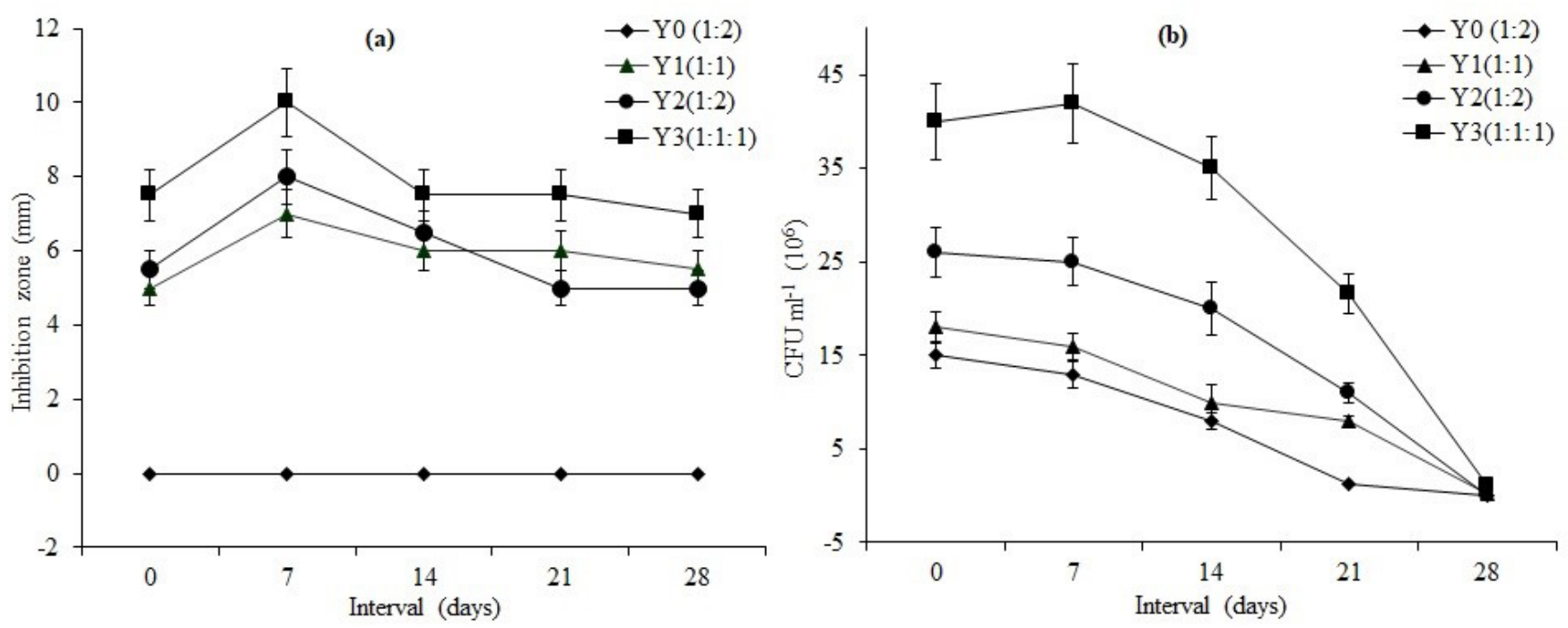

Figure 3. Functional attributes of probiotic yoghurt as (a) antibacterial activity and (b) total viable count of three preparations probiotic yoghurt refrigeration storage and comparison with control indicating better performance of Y3.

Figure $3 b$. It was observed that whey taken fromY0 has zero antimicrobial activity while other combination differ significantly $(\mathrm{P}<0.05)$. Increasing trend was observed in all combination except Y0 after 7 day of storage and then it decreasing trend started. Y3 has the better antibacterial activity on the first day (750 AU/ml) that increased after 7 days to $1000 \mathrm{AU} / \mathrm{ml}$. At the end of storage activity declined to $700 \mathrm{AU} / \mathrm{ml}$. The maximum activity was observed in $\mathrm{Y} 3$ as this combination has three probiotic cultures including $L$. acidophilus that further revealed that there was symbiotic relationship among cultured bacteria. Y3 combination has best keeping quality and overall acceptability at the end of storage. In the literature, Varghese \& Haridas (2007) analyzed the whey obtained from yoghurt for antibacterial activity and found that it has antibacterial activity against $S$. aureus and many other pathogenic bacteria.

Sensory evaluation of yoghurt in term of texture: Texture is one of important parameter to assess the sensory quality of probiotic yoghurt. Grading score for texture of various probiotic yoghurts are presented Figure 4a. Maximum acceptable texture was observed at 14 days of storage in Y 3 combination. It was noted that texture of this preparation become better after two week storage and then started to decline. Present findings confirm the previous results that $\mathrm{Y} 3$ preparation has higher apparent viscosity as compare to other preparation This attribute of yoghurt was earlier reported by Aryana \& Mcgrew (2007) that addition of some of prebiotic like inulin HP improve the texture and body yoghurt. In the same way Goncu \& Alpkent (2005) noted significant variation in their findings for concentration of strains of culture bacteria on texture of cheese. In the same lines, Khandelwal et al. (2014) reported continues loss of texture during refrigerated storage of yoghurt-cheese.

Color: This is an important attribute of sensory parameter that attracts the consumers. Scores point for various combination of yoghurt is illustrated in the Figure $4 \mathrm{~b}$. Significant difference $(\mathrm{P}<0.05)$ was observed in three combinations. At Zero day the highest score was denoted to Y0 followed by $\mathrm{Y} 3, \mathrm{Y} 1$ and $\mathrm{Y} 2$ respectively. Maximum changes at the 28 days of storage were observed in $\mathrm{Y} 0$ and minimum in $\mathrm{Y} 3$ possible due to the preventive effects of probiotic strains. These results correlate with the findings of Sarkar et al. (1996) who found wide variations in the scores of colour of yoghurt. However, Aryana \& Mcgrew (2007) determined that there was no difference in the colour of yoghurt due to storage. Our results are in line with the finding of Khandelwal et al. (2014) who reported the decreasing trend in the color of yogurt-cheese with the passage of time.

Flavour: Data regarding flavour mean score was illustrated in the Figure $4 \mathrm{c}$ that revealed at 0 days flavour of the yoghurt obtained with various preparations is less accepted than the subsequent intervals during storage. Most acceptable flavour of yoghurt was reported for $\mathrm{Y} 3$ it might be due to presence of the different strains of lactic acid bacteria including acetaldehyde producing strains that enhance the flavor during storage. Acetaldehyde production by lactic acid bacteria was previously reported by Hess et al. (1997) and Aryana \& Mcgrew (2007). Previously, Sarkar et al. (1996) reported that the yoghurt taste was increased during few days of initial storage and subsequently it declined throughout entire storage period.

Overall acceptability: Overall acceptability of yoghurt results were presented in Figure 4d. The highest score of overall acceptability of prepared probiotic yoghurt was found in Y3, followed by Y0, Y2, and Y1 respectively, at 0 day. Chemical results of $\mathrm{Y} 3$ are better than Control while sensory score is higher in control. However, this pattern was changed at the end of study. The significant variation in these results was result of rheological and biochemical change in the in yoghurt preparations. Y3 had maximum acceptability, as bacterial culture of this combination showed the highest viable count during storage. It was further noted that all combinations except Y0 day in the acceptable region. Scores given to overall acceptability are consistence with values of other parameter like colour and flavour. Previously, it 

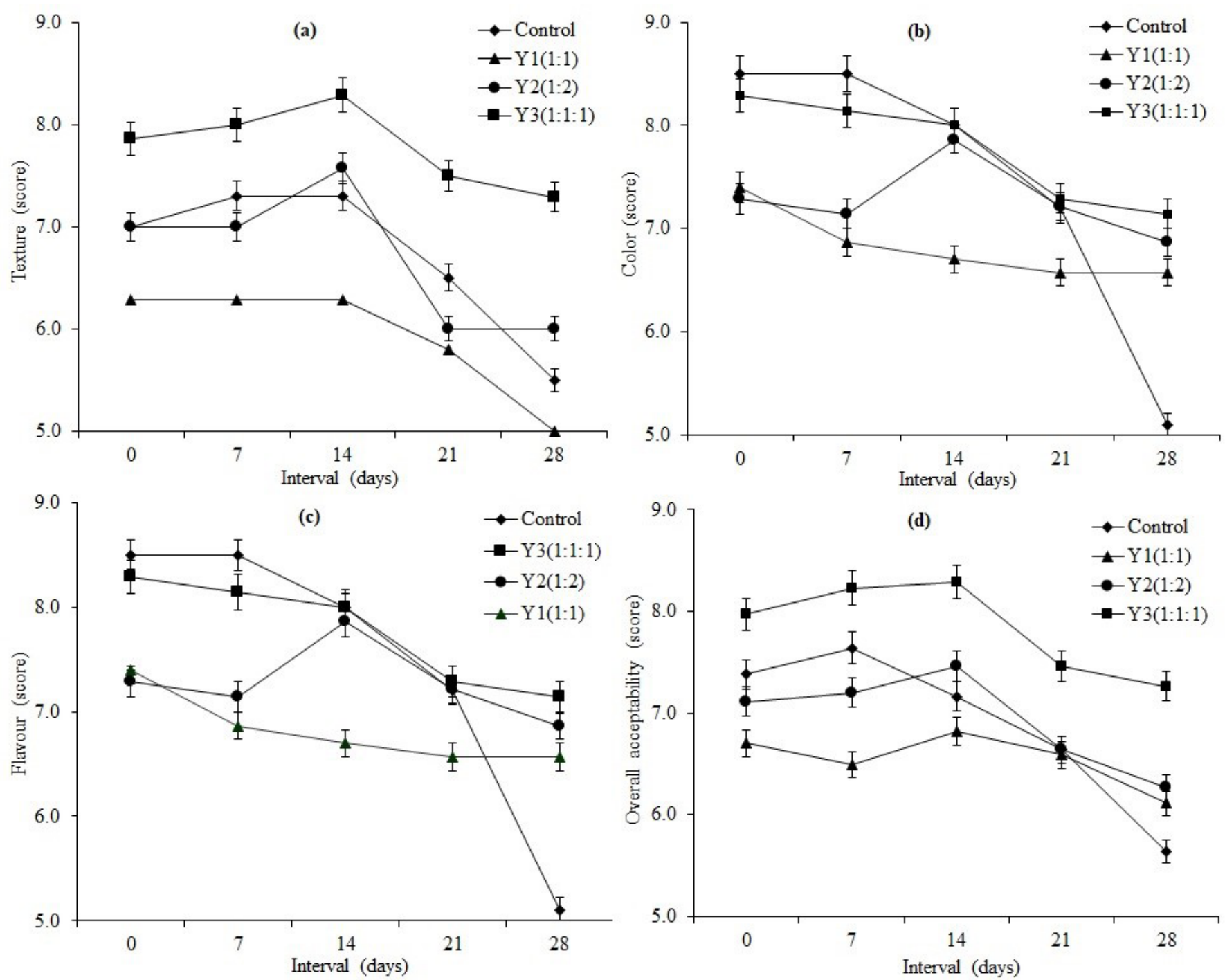

Figure 4. Sensory evaluation of probiotic yoghurt (a) texture, (b) color, (c) flavour and (d) overall acceptability of three preparations probiotic yoghurt during refrigeration storage and comparison with control indicating higher scores for Y3.

was reported by Sarkar et al. (1996) that misti dahi samples got average score 6.20 for overall acceptability.

Conclusion: It was concluded that micro flora of dahi is a rich source of probiotic lactic acid bacteria that can be used for the preparation of different fermented dairy product and probiotic yoghurt was one of them. However, to food processors and manufactures it is not economical to use additional probiotic strains along use routine culture bacteria. In present investigation, we have identified probiotic culture bacteria i.e Lactobacillus bulgaricus and Streptococcus thremophillus. The probiotic property yoghurt can be enhanced by addition of Lactobacillus acidophilus stains. In addition, changes in the technological, functional, sensory attribute during the refrigerated storage indicate that among the different preparations yoghurt made with in 1:1:1 ratio with selected probiotic strain is more useful.

\section{Recommendation}

It is recommended that probiotic yoghurt with multi strains (Y3) has better keep quality, good flavour and sensation values and longer viability of probiotic bacteria. Future studies may be focus on economic assessment for the identification of viable strategies for the commercialization of these technologies.

\section{References}

Akalın, A. S., Unal, G., Dinkci, N., \& Hayaloglu, A. A. (2012). Microstructural, textural, and sensory characteristics of probiotic yogurts fortified with sodium calcium caseinate or whey protein concentrate. Journal of Dairy Science, 9(7), 3617-3628. http://dx.doi. org/10.3168/jds.2011-5297. PMid:22720919.

Ali F S, Saad O A, Salwa A G H (2013). Probiotic stability of yoghurts during refrigerated storage. Egypt Acad J Biolog Sci 5(2):9-19. Retrived from: http://microbiology.eajbs.eg.net/pdf/vol5.n2/2.pdf 
Aryana, K. G., \& Mcgrew, P. (2007). Quality attributes of yogurt with Lactobacillus casei and various Prebiotics. Lebensmittel-Wissenschaft + Technologie, 40(10), 1808-1814. http://dx.doi.org/10.1016/j. lwt.2007.01.008.

Association of Official Analytical Chemists - AOAC. (2000). Dairy products (16th ed., vol. 2). Wasington DC: AOAC International.

Bandiera, N. S., Carneiro, I., Silva, A. S., Honjoya, E. R., Santana, E. H., Aragon-Alegro, L. C., \& Souza, C. H. (2013). Viability of probiotic Lactobacillus casei in yoghurt: defining the best processing step to its addition. Archivos Latinoamericanos de Nutricion, 63(1), 58. PMid:24167959.

Cruz, A. G., Castro, W. F., Faria, J. A. F., Bolini, H. M. A., Celeghini, R. M. S., Raices, R. S. L., Oliveira, C. A. F., Freitas, M. Q., Conte Júnior, C. A., \& Mársico, E. T. (2013). Stability of probiotic yogurt added with glucose oxidase in plastic materials with different permeability oxygen rates during the refrigerated storage. Food Research Journal, 51(2), 723-728. http://dx.doi.org/10.1016/j.foodres.2013.01.028.

Donkor, O. N., Henriksson, A., Singh, T. K., Vasiljevic, T., \& Shah, N. P. (2007). ACE-inhibitory activity of probiotic yoghurt. International Dairy Journal, 17(11), 1321-1331. http://dx.doi.org/10.1016/j. idairyj.2007.02.009.

Georgala, A. I. K., Taskalidin, E., Kandarakis, I., \& Kalantzopoulos, G. (1995). Flavour production in the ewe, so milk yoghurt by single strains and combinations of S. thermophilus and L. bulgaricus isolated from traditional Greek yoghurt. Journal of Food Technology, 75(3), 271-279.

Giraffa, G. (2012). Selection and design of lactic acid bacteria probiotic cultures. Engineering in Life Sciences, 12(4), 391-398. http://dx.doi. org/10.1002/elsc.201100118.

Goncu, A., \& Alpkent, Z. (2005). Sensory and chemical properties of white pickled cheese produced using kefir, yoghurt or a commercial cheese culture as a starter. International Dairy Journal, 15(6-9), 771776. http://dx.doi.org/10.1016/j.idairyj.2004.10.008.

Granato, D., Branco, G. F., Cruz, A. G., Faria, J A F., \& Shah, N. P. (2010). Probiotic dairy products as functional foods. Comprehensive Reviews in Food Science and Food Safety, 9(5), 455-470. http://dx.doi. org/10.1111/j.1541-4337.2010.00120.x.

Harun-ur-Rashid, M., Togo, K., Ueda, M., \& Miyamoto, T. (2007). Identification and characterization of dominant lactic acid bacteria isolated from traditional fermented milk (yoghurt) Dahi in Bangladesh. World Journal of Microbiology \& Biotechnology, 23(1), 125-133. http://dx.doi.org/10.1007/s11274-006-9201-x.

Hess, S. J., Roberts, R. F., \& Ziegler, G. R. (1997). Rheological properties of nonfat yogurt stabilized using lactobacillus delbrueckii ssp. bulgaricus producing exopolysaccharide or using commercial stabilizer systems. Journal of Dairy Science, 80(2), 252-263. http://dx.doi.org/10.3168/ jds.S0022-0302(97)75933-2.

Hoover, D. G., \& Harlander, S. K. (1993).Screening methods for detecting bacteriocins activity. In Hoover DG \& Steenscr LR, editors. Bacteriocins of lactic acid bacteria (3rd ed.). San Diego: Academic Press Inc. http://dx.doi.org/10.1016/B978-0-12-355510-6.50010-5.

Kavas, N., \& Gokhan, K. (2016). Functional probiotic yoghurt production with Pomegranate (Punicagranatum L.) Juice concentrate fortification. J Sci Res Reports, 10(2), 1-10.

Keogh, M. K., \& O’Kennedy, B. T. (1998). Rheology of stirred yogurt as affected by added milk fat, protein and hydrocolloids. Journal of Food Science, 63(1), 108-112. http://dx.doi.org/10.1111/j.1365-2621.1998. tb15687.x.
Khandelwal, P., Upendra, R. S., \& Zeynab, R. A. (2014). Optimization of the process parameters for the preparation of synbiotic yoghurtcheese. Int J Pharma Sci Res, 5(12), 980-987.

Larmond, E. (1977). Laboratory methods for sensory evaluation offood. Beltsville: National Agricultural Library.

Lee, W. J., \& Lucey, J. A. (2004). Structure and physical properties of yogurt gels: effect of inoculation rate and incubation temperature. Journal of Dairy Science, 87(10), 3153-3164. http://dx.doi.org/10.3168/ jds.S0022-0302(04)73450-5. PMid:15377593.

Mattila-Sandholm, T., Myllärinen, P., Crittenden, R., Mogensen, G., Fonden, R., \& Saarela, M. (2002). Technological challenges for future probiotic foods. International Dairy Journal, 12(2-3), 173-182. http:// dx.doi.org/10.1016/S0958-6946(01)00099-1.

Nguyen, H. T. H., Ong, L., Kentish, S. E., \& Gras, S. L. (2014). The Effect of fermentation temperature on the microstructure, physicochemical and rheological properties of probiotic buffalo yoghurt. Food and Bioprocess Technology, 7(9), 2538-2548. http://dx.doi.org/10.1007/ s11947-014-1278-x.

Olson, D., \& Aryana, K. (2008). An excessively high Lb acidophilus inoculation level in yoghurt lower product quality during storage. Lebensmittel-Wissenschaft + Technologie, 41(5), 911-918. http:// dx.doi.org/10.1016/j.lwt.2007.05.017.

Patel, J. J., Antony Kathayat, B., \& Patel, K. T. (2018). Antibacterial activity of dahi prepared from dairy industry, cottage and house hold against food borne pathogens. International Journal of Current Microbiology and Applied Sciences, 7(1), 2173-2179. http://dx.doi. org/10.20546/ijcmas.2018.701.261.

Saccaro, D. M., Tamime, A. Y., Pilleggi, A. L. O. P. S., \& Oliveira, M. N. (2009). The viability of three probiotic organisms grown with yoghurt starter cultures during storage for 21 days at $4^{\circ} \mathrm{C}$. International Journal of Dairy Technology, 62(3), 397-404. http:// dx.doi.org/10.1111/j.1471-0307.2009.00497.x.

Sarkar, S., Kuila, P., \& Misra, A. (1996). Organoleptic, microbiological and chemical quality of misti dahi sold in different districts of West Bengal. Indian Journal of Dairy Science, 49, 54-61.

Steel, R. G. D., Torrie, J. H., \& Dickey, D. A. (1997). Principles and procedures of statistics: a biometrical approach (3rd ed.). New York: McGraw Hill Book Co. Inc.

Theunissen, J., \& Witthuhun, C. (2004). Probiotic contents truth or fiction. South African Food Review, 31, 15-17.

Tsiraki, M. I., Karam, L., Abiad, M. G., Yehia, H. M., \& Savvaidis, I. N. (2017). Use of natural antimicrobials to improve the quality characteristics of fresh "Phyllo" - A dough-based wheat product shelf life assessment. Food Microbiology, 62, 153-159. http://dx.doi. org/10.1016/j.fm.2016.10.001. PMid:27889143.

Varghese, J., \& Haridas, M. (2007). Prospects of jackfruit blend yoghurt whey. World J Dairy Food Sci, 2(1), 35-37. Retrieved from: https:// www.idosi.org/wjdfs/wjdfs2(1)/6.pdf

Vinderola, C. G., Mocchiutti, P., \& Reinheimer, J. A. (2002). Interactions among lactic acid starter and probiotic bacteria used for fermented dairy products. Journal of Dairy Science, 85(4), 721-729. http:// dx.doi.org/10.3168/jds.S0022-0302(02)74129-5. PMid:12018416.

Wang, J., Guo, Z., Zhang, Q., Yan, L., Chen, Y., Chen, X., Liu, X.-M., Chen, W., \& Zhang, H.-P. (2010). Effect of probiotic L. casei Zhang on fermentation characteristics of set yogurt. International Journal of Dairy Technology, 63(1), 105-112. http://dx.doi.org/10.1111/j.14710307.2009.00556.x.

Weerathilake, W. A. D. V., Rasika, D. M. D., Ruwanmali, J. K. U., \& Munasinghe, M. A. D. D. (2014). The evolution, processing, varieties and health benefits of Yogurt. Int J Sci Res Pub, 4(4), 1-10. 